\title{
Det kongelige Biblioteks fremtid
}

af overbibliotekar Erland Kolding Nielsen

Den 26. november 1992 indgik den daværende regering, Socialdemokratiet, Centrumdemokraterne, Det radikale Venstre og Kristeligt Folkeparti en aftale om Finansloven for 1993, hvori indgik en rækkestore kulturinvesteringer i hovedstaden. Blandt dissevar en ny bygning til Det kongelige Bibliotek p̊̊ Københavns havnefront på Christians Brygge-kajen. I denne artikel skildrer overbibliotekaren vedtagelsens baggrund og perspektiver med et udblik over pladsproblemernes historie. Den vil blive efterfulgt af artikler med jævne mellemrum frem til bygningens indvielse $i 1996$.

Det kongelige Bibliotek har altid ligget på Slotsholmen $\mathrm{i}$ tæt forbindelse med konge-, stats- og folkemagten, hvilket afspejler sig i udviklingen af dets opgaver fra kongens private bibliotek til landets nationalbibliotek. Biblioteket har sin oprindelse i kongens eget bibliotek, der i skiftende perioder af sin eksistens frem til 1673 havde til huse på Københavns Slot. Kong Frederik III havde i modsætning til sin far omfattende boglige interesser og begyndte allerede få år efter sin tronbestigelse at opbygge et fyrstebibliotek, til hvilket han 1667 til 1673 efter tegninger af sin bygmester Albert Matthiesen lod opføre en stor bygning for enden af Tøjhushavnen imellem faderens Tøjhus og Proviantgård. Bygningen rummedeoprindeligt et kanonmagasin i stueetagen, bibliotek i første og kunstkammeret i anden etage, men i løbet af det 19. århundrede overtog Det kongelige Bibliotek efterhånden hele bygningen. $\mathrm{Om}$ denne smukke bygning i klassisk stil samt om dens fornemme indretning i barok er der skrevet overordentligt meget, ikke mindst efter 1906, hvor Rigsarkivet ved Det kongelige Biblioteks udflytning overtog bygningen, og hvor - med arkitekturhistorikeren Hakon Lunds ord - "den groveste og mest tilintetgørende ombygning af et uvurderligt historisk hus fandt sted under arkitekt Ludvig Andersensledelse". Bygningen står der endnu, men kun gennem det overleverede kilde- og billedmateriale er det i dag muligt at danne sig et 
indtryk af de prægtige fysiske rammer omkring det ældste, store Kongelige Bibliotek, som det kaldtes i modsætning til håndbiblioteket på Christiansborg.

\section{Slotsholmsbygningen}

Bibliotekets pladsproblemer voksede støt gennem det 19. århundrede, og $\mathrm{i}$ 1867 rejste den unge overbibliotekar Christian Bruun (1862-1901) første gang kravet om en ny bygning. Der gik imidlertid 12 år, før man i 1879 nedsatte "Kommissionen til Overvejelse af Spørgsmålet om Tilvejebringelseog Omordning af forskellige offentlige Bygninger". Kort efter anmodede Bruun arkitekten Hans J. Holm om at udarbejdeet detaljeret program for en ny biblioteksbygning. Kommissionens betænkning fra 1883 byggede på Holms plan, og selvom den i første omgang skrinlagdes, dannede skitserne grundlag for det endelige projekt, som en ny byggekommission, den tredie, nedsati 1892, i1895 indstillede til Kultusministeriet. Et hovedproblem havde nemlig været placeringen af biblioteket, hvor en ny kommission nedsat i 1884 overvejede fire forskellige muligheder. Kommissionen indstillede to forslag, Kultusministeriet valgte det ene, men Finansudvalget afgjorde sagen med at vedtage det andet. Den første del af byggesummen bevilgedes på Finansloven for 1896-97, samtidig med at Finansudvalget forlangte projektet noget indskrænket ved, at visse erstatninger skulle udredes af byggesummen på 1.5 mill. kroner.

Et nyt, beskåret projekt måtte derfor fremlægges i december 1896. Udgifterne til bygningens pilotering måtte forhøjes, nu da man skulle til at bygge i den opfyldte Tøjhushavn. Det var dog lykkedes at få nedsat erstatningssummen, og den væsentligste besparelse var nået ved at lade den gamle galejbygning fra 1602 indgå i den nye bygnings underetage. Trods ihærdig modstand fra Bruun og Holm fjernede Kultusministeriet en tværfløj, der skar den indre gård over i to. Ligeledes blev reolkapaciteten beskåret, således at der nu måtte regnes med udvidelser allerede efter 30 år og ikke, som oprindeligt planlagt, efter 40 år. Loven om Det kongelige Biblioteks udbygning blev underskrevet den 22. marts 1897.

Selve byggeriet startede umiddelbart efter, men skred meget langsomt frem. Tre år senere var man kun nået til pilotering og cementering af grunden. Undervejs tumlede arkitekten stadig med alternative planer, bl.a. om at få genindført den tværfløj, der var så vigtig for hele husets funktionsdygtighed, 


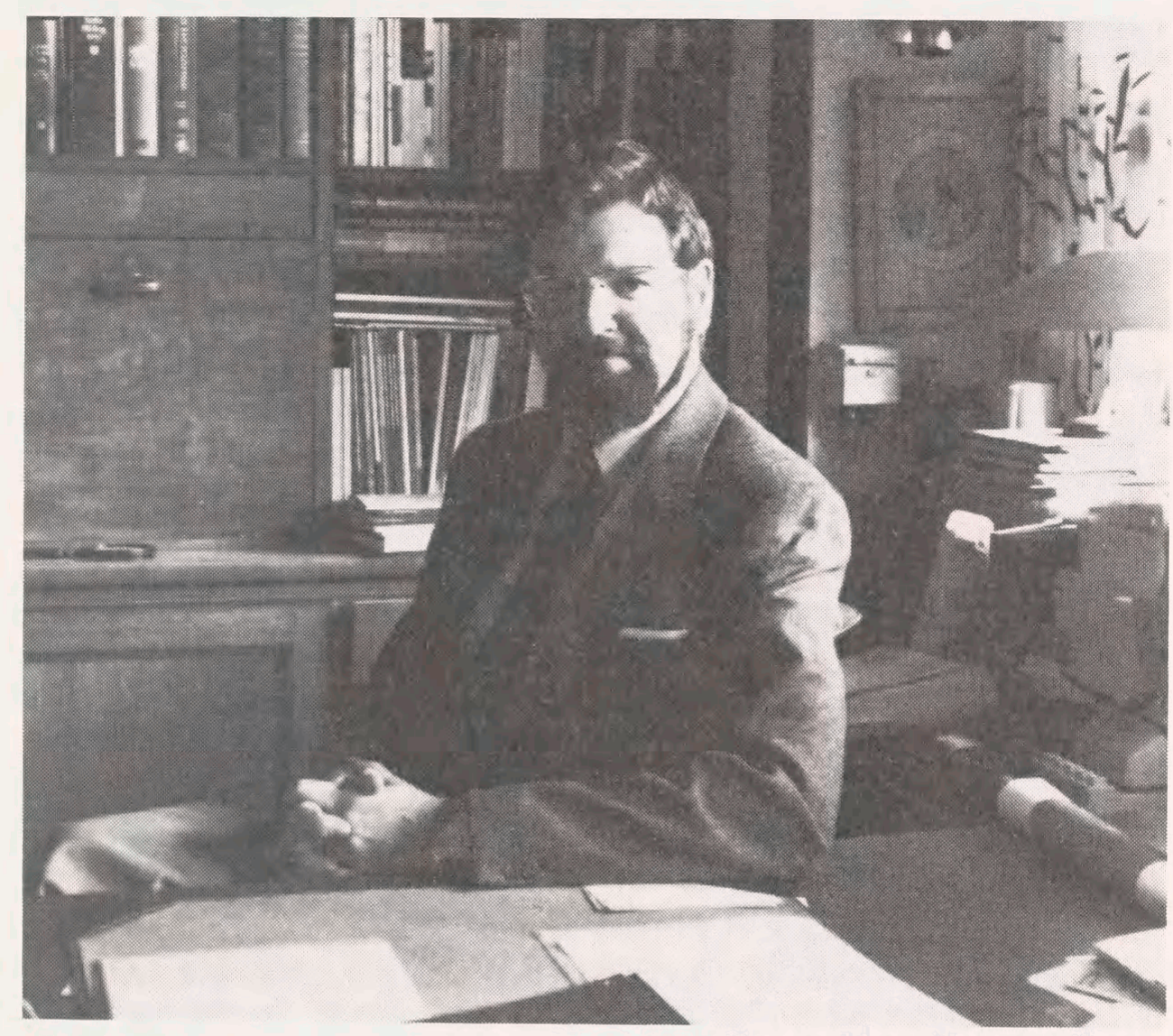

Overbibliotekar Erland Kolding Nielsen

men som ministeriet havde fjernet. Endvidere blev hovedindgangen, der først var planlagt fra havnesiden, flyttet til Tøjhusgården, den nuværende bibliotekshave, og facaden mod havnen, der oprindeligt var tænkt som hovedfacade, blev nu bagside. Tøjhusgården blev planlagtomdannet til et haveanlæg med adgang gennem en gennemskæring i den gamle biblioteksbygning. Som følge af regeringsskiftet 1901 lykkedes det Holm og den nye overbibliotekar H.O. Lange (1901-24) at få gennemført nogle af disse ændringer, således først og fremmest tværbygningen. Byggeriet var nu så fremskredet, at det var i yderste øjeblik at ændre planerne. Men takket være Holms stædighed var byggearbejdet dog lagt til rette på en sådan måde, at opførelsen af tværfløjen endnu lod sig udføre, og at hele planen kunne vendes. Selve den nye biblioteksbygning påbegyndtes i 1902 og stod færdig i efteråret 1906 og stemmer næsten overens med den oprindelige plan fra 1895. 


\section{Nye pladsproblemer}

På trods af husets størrelse varede det ikke længe, før det viste sig for lille. Ved ind vielsen var magasinerne kun halvt fyld top. Man regnedemed at have plads til 30 års accession, og derefter var detoprindeligt planen at fordoblekapaciteten ved at bygge en ny bygning spejlvendt på det opfyldte havneområde, der imidlertid i 1920 stod færdig som have, kaldet Det kongelige Biblioteks have til trods for, at hverken grund eller have administrativt er underlagt Det kongelige Bibliotek. Allerede i 1924 var pladsmangelen så stor, at bibliotekets eget varmeværk blev fjernet for at give plads til avissamlingen, der dog igen i 1926 som den første samling efterfulgt af mange senere måtte flyttes ud af bygningen, nemlig til Universitetsbiblioteket i Fiolstræde. Biblioteket blev i stedet tilsluttet Slotsholmens Varmecentral, en ombygning, der ganske vist betød, at varme- og kulkælder kunne indrettes til magasiner af tvivlsom kvalitet, men yderligere magasinrum fik nu temperatur- og klimaproblemer.

Ikke bare samlingerne savnede plads, personalet voksede og måtte anbringes i kontorer, bl.a. i magasinerne, der af lysmæssige grunde var indrettet med ristegulve. Dette kunne nok have sin charme, men næppe leve op til selv datidens mere beskedne krav til kontorer.

Alleredei 1930 ernestod det klart for ledelseog ministerium, at udvidelser var nødvendige. I 1943 nedsattes igen en kommission til at se på sagen. Historien gentog sig i flere henseender som for trekvart århundrede siden. Planer, nye planer, forsinkelser, halve eller kvarte løsninger over flere årtier. Bestandigenedprioriteringer, uenighed og brudteløfter er det indtryk, man får af at studere sagens udvikling.

I 1963 var forholdene helt kaotiske. Bygningen, der oprindeligt var beregnet til 40 ansatte, rummede nu over 200 . Der var afsat plads til højst 900.000 bøger, men bestanden var vokset til 1.5 mill. Der var indrettet interimistiske kontorer overalt, ikke mindst på jernristegulvene ude i magasinerne. Reolerne begyndte at krybe op ad trapperne, ja selv på hvælvingsloftet opstilledes reoler.

I 1954 forelå der et forslag til udbygning af kgl. bygningsinspektør Axel Maar. Planen gik ud på dels at udnytte den eksisterende plads mere effektivt, og det skulle ske ved at indlægge etagedæk i Danske Sal og opfylde de to indvendige gårde, hvilket kunne give ekstra magasinplads og nye kontor- og 
publikumsarealer. Desuden blev der projekteret en kontorbygning ud mod havnen. I 1966 blev denne sidste del - ca. en trediedel af den oprindelige plan - realiseret, da Aksel Maars efterfølger, kgl. bygningsinspektør Preben Hansen, opførte den såkaldteNy Bygning mod Christians Brygge. Detmesteaf personalet kunne nu flytte ud fra denødtørftige kontorer på ristegulvene, men bygningen ødelagde unægteligt den smukke gamle biblioteksfacade mod havnen, der blev fuldstændig skjult. Bygningens arkitektur betragtes af mange i dag som en æstetisk katastrofe ud mod den sårbare havnefront. Det er på alle måder et skrabet byggeri både funktionelt og arkitektonisk. Der har fra starten været problemer med betonen, der nu er 25 gammel, og en lang række skader har meldt sig hele tiden.

De to næste etaper af udbygningen - opfyldning af de indre gårde og Danske Sal - er gentagne gange blevet udskudt, i begyndelsen af 1980'erne definitivt, formentligt fordi man har indset, at biblioteksbygningen på Slotsholmen alligevel aldrig ville kunne rumme samlingerne i deres helhed. Der blev imidlertid ikke sat noget istedet, og imens voksedeproblemerne. Biblioteket fik sit første fjernmagasin, et tidligere ostelager i Sydhavnen, i 1965. I 1972 kom Vestindisk Pakhus til, og herefter gik det stærkt. En kælder i Hermodsgade fra 1973, en kælder under Proviantgården udgravet i 1975 og en bagbygning i Havnegadekom til i1979. I 1983 overtog manen industribygning på Lergravsvej på Østamager fra ca. 1950, ejet af Staten ved Forsvarsministeriet, udlejet til Kulturministeriet og stillet til rådighed for biblioteket. Men samtidig blev bibliotekets etageareal i Vestindisk Pakhus reduceret fra fem til to. I alt havde biblioteket over $13.000 \mathrm{~m}^{2}$ fjernmagasiner spredt over København i 1986 ud over de knap $9.000 \mathrm{~m}^{2}$, Slotholmsbygningskomplekset i forvejen rummede.

En ny administrationsfløj blev opført i den vestre gård i årene 1979-80, igen med Preben Hansen som arkitekt. Bygningen er opført i "hakket" mellem den smallere vestlige del af nordfløjen ud mod haven og den bredere, centrale og østlige del. Denne asymmetri skyldes, at den centrale og østlige del af nordfløjen er bygget oven på Galejhuset. Huset er ganske vist en betonkonstruktion, men skalmuret i røde mursten, en arkitektonisk indrømmelse til de omgivende røde murmasser. Ud over kontorer rummer de to nederste etager de første klimastyrede sikringsbokse i bibliotekets historie. I de allerseneste år er der i øvrigt sket den første udvidelse af publikumsfaciliteterne siden 1906. Dette er sket ved udflytning af funktioner og afdelinger ud fra en 
voksende erkendelse af, at der skulle ske en omprioritering af forholdet mellem arealet til publikum, personale og samlinger.

\section{Nye løsninger}

I gennem mindst to årtier har det således stået klart, at Det kongelige Biblioteks pladsproblemer ikke ville kunne løses på stedet. Der krævedes nytænkning, og den ville blandt andet kunne medføre, at biblioteket måske skulle flytte for tredje gang i dets nu mere end 300 årige bygningshistorie. De hidtidige planer var blevet skrinlagt uden at der var sat nye i stedet. Det har gennem mange år stået klart for alle parter, at bibliotekets problemer for en stor dels vedkommende havdesinårsag i pladsforholdeneog i utidssvarendefunktions-og arbejdsvilkår for varetagelsen af bibliotekets opgaver over for både publikum og samlinger.

I Firkløverregeringens moderniseringprogram indgik også et moderniseringskrav til Det kongelige Bibliotek. Mens ministeriet nok overvejende havde tænkt på organisatoriske og funktionelle forandringer, anså den i 1985 udnævnte ny overbibliotekar de fysiske og bygningsmæssige problemer for så væsentlig en medvirkende årsag til bibliotekets problemer og dermed også som en mulig hindring for alle moderniseringsbestræbelser, at han ved sin ansættelse stillede krav om, at bibliotekets fysiske forhold nu blev underkastet en gennemgribende analyse, der skulle munde ud i en eller flere helhedsplaner for bibliotekets fysiske udbygning, som ministeriet måtte tage stilling til. Kulturminister Mimi Jacobsen accepterede synspunktet, og som led i moderniseringsprogrammet for biblioteket, der påbegyndtes i sommeren 1986, nedsattes en arbejdsgruppe med deltagelse af repræsentanter for Kulturministeriet, Undervisningsministeriets Byggedirektorat og bibliotekets ledelse, der i 1987 afsluttede sin analyse med en udførlig rapport Det kongelige Bibliotek ifremtiden. Fysiske udbygningsbehov og byggemuligheder, der dog først af politiske og interne årsager kunne offentliggøres i juni 1989. Arbejdsgruppen analyserede snart sagt alle partielle udbygningsmuligheder på Slotsholmen, der dog alle viste sig at være helt utilstrækkelige i forhold til bibliotekets kapacitetskrav og funktionsbehov. Rapporten konkluderedederfor, at der kun var to muligheder for at løse Det kongelige Biblioteks fysiske udbygningsbehov i fremtiden. Enten måtte man bygge et helt nyt bibliotek uden for Slotsholmen, eller også måtte man planlægge med en dobbelt udbygning af henholdsvis 


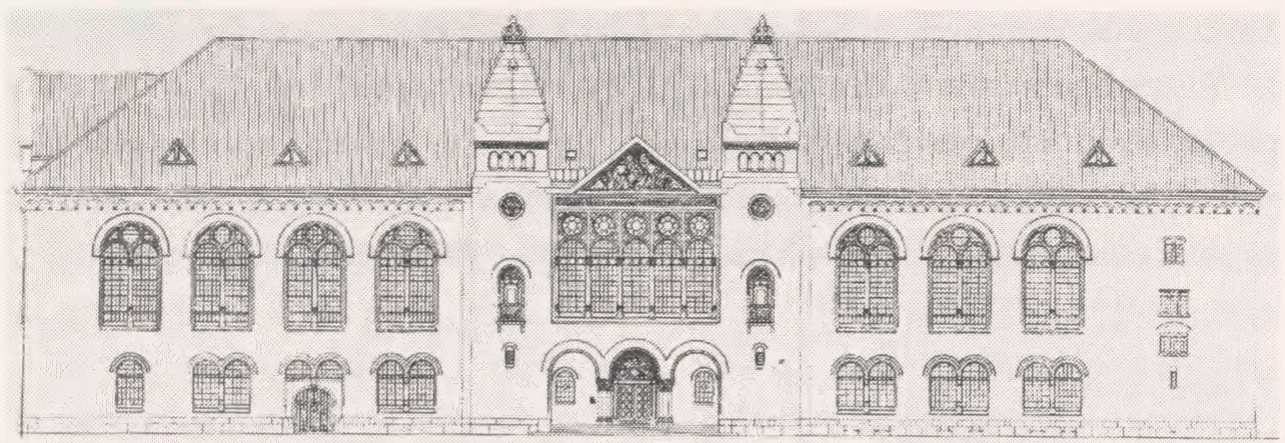

Tegning af Det Store Kongelige Bibliotheks forside, 1906

magasinfunktionernef. eks. i tilknytning til Københavns Universitet på Amager og af publikumsfunktionerne på Slotsholmen.

Arbejdsgruppen indstillede enstemmigt den sidstnævnte løsning til ministeriets beslutning. Indstillingen var ledsaget af en række skitsetegninger af en mulig udbygning på havnefronten udført af arkitekt Michael Jørgensen fra kgl. bygningsinspektør Gehrdt Bornebusch' Tegnestue. Hermed opgav man samtidigt at bygge videre på tidligere planer, der indebar så væsentlige indgreb i Holms gamle bygning. Rapporten udkom i bogform, og dens konklusioner blev vel modtaget såvel af pressen som af den øvrige offentlighed.

Ministeriet accepterede den dobbelte udbygning som løsning på Det kongelige Biblioteks problemer, og den har siden været grundlaget for den fysiske og den økonomiske planlægning. I august 1990 indgik såvel centralmagasinløsningen på Amager som udbygningen i havnefronten som højt prioriterede projekter i kulturminister Ole Vig Jensens storslåede kulturelle udbygningsplan for statslige kulturinstitutioner Plan 2000, der fremlagdes den 29. august 1990 i finanslovsforslaget for 1991.

På grund af finansieringsproblemer stod planen dog noget i stampei den følgende tid, men der har konstant været arbejdet med at tilvejebringe forudsætningerne for dens realisering. I foråret 1990 udarbejdede biblioteket således i dybeste hemmelighed på foranledning og finansieret af entreprenørfirmaet Monberg \& Thorsen i samarbejde med Palle Leif Hansens arkitektfirma et nyt projekt, der dels indeholdt en fuldstændig beregning af alle omkostninger ved et byggeri i havnefronten, dels et udbygget rumprogram for udvidelsen. Og i foråret 1991 bevilligede Kulturministeriet 75 mio. kr. (senere forhøjet til 92 mio.) kr. til førsteetape påca. $8.000 \mathrm{~m}^{2}$ af magasinudbygningen ved Københavns 
Universitets Amagerkompleks, hvortil der indbydes til arkitektkonkurrence i 1993. Hermed var den ud fra et samlingsbevaringssynspunkt mest påtrængende del af fremtidsprojektet påbegyndt.

1992 blev endelig året, hvor den anden halvdel, Havnefronten, seks år efter ideens undfangelse, skiftede karakter fra luftkastel til virkelighed.

\section{Plan 2000}

Efter talrige forberedelser og opdateringer af planerne fra biblioteket og Kulturministeriets side fremsatte regeringen hovedparten af $P$ lan 2000 -forslagene til forhandling som fremrykkede statslige investeringer $\mathrm{i}$ forbindelse med finanslovsforhandlingerne. I Kulturministeriets notat af 6 . november til brug herfor, der er forfattet i det nyoprettede KulturpolitiskeSekretariat, hedder det om Det kongelige Bibliotek:

“Det kongelige Bibliotek er Danmarks Nationalbibliotek, Københavns Universitetsbibliotek og Danmarks Bogmuseum. Biblioteket rummer de videnskabeligt og kulturelt mest betydningsfulde samlinger i Nordeuropa. Stigende brugerpres og stor tilvækst $\mathrm{i}$ bogbestanden nødvendiggør en udbygning af biblioteket. I Plan 2000 indgår derfor en tilbygning til Bibliotekets hovedsæde på Slotsholmen ud imod havnefronten. Tilbygningen vil have et areal på godt $10.000 \mathrm{~m}^{2}$.

Ved tilbygningen opføres en helt ny forbygning på kajen ved Christians Brygge. Bygningen vil skabe en moderne, rationel og indbydende ramme for bevaring og formidling af Danmarks nationale bogskat, for bibliotekets brugere og for nye udadvendte aktiviteter. Tilbygningen vil ikke bare give biblioteket en markant, åben og indbydende facade af høj arkitektonisk standard, men også give Københavns havnefront et element af international klasse.

I tilknytning til udbygningen er det planen at opføre og indrette mødelokaler, der samtidig kan anvendes som en lille koncertsal. Derved opfyldes et behov fra det klassiske musikliv samt musikkonservatorierne, og med sin placering ved havnefronten vil koncertsalen fremstå repræsentativt smuk.

I forbindelse med gennemførelsen af projektet skal udskrives en arkitektkonkurrence. En sådan kan gennemføres på seks måneder. Hvis denne udskrives primo 1993, kan åbningen af det nye Kgl. Bibliotek finde sted i forbindelse med Kulturby 96.

Det samlede projekt er anslået til en totaludgift på 400 mill. kr....". 


\section{Et nyt Kongeligt Bibliotek}

I et særskilt notat udarbejdet af Det kongelige Biblioteks ledelse, der var bilag til forhandlingsoplægget, præsenteres projektet nærmere under overskriften et nyt Kongeligt Bibliotek. Presentation af Havnefrontsprojektet. Det understreges, at den ny bygning $i$ havnefronten skal opføres $i$ tilslutning til den gamle bygning som et byggeri af høj arkitektonisk kvalitet, der respekterer både havnefrontens karakter og profil og tager hensyn til de arkitektoniske kvaliteter i Holms bygning, samtidigt med at byggeriet skal have monumental karakter. Byggeriet vil mere end fordoble bygningsarealet og tredoble de publikumsvendte funktioner. Holms gamle bygning skal samtidig renoveres, således at derskabesetsammenhængendebygningskompleks, hvor helearealetnyindrettes.

Udbygningen og omformningen muliggør, at Det kongelige Bibliotek som national- og universitetsbibliotek, bog- og fotomuseum kan videreføres $\mathrm{i}$ sin hidtidige centrale placering, hvilketer af væsentlig betydning for betjeningen af forskere og studerende ved Universitetet og forskningsmiljøernei København. Men samtidigændres konceptet for bibliotekets opgaver og fremtrædelsesform på så væsentlige punkter, at det kan være på sin plads at fremhæve, at der er tale om et helt nyt bibliotekskoncept med større vægt på at opfylde behovet for oplevelser og funktioner. Udgangspunktet er at biblioteket med sine i nordisk målestok største, sjældneste og rigeste samlinger er hele nationens bibliotek, og derfor må der lægges større vægt på at synliggøre de kulturelle opgaver og forpligtelser på en sådan måde, at adgangen ikke bare til forskningsmæssig og studiemæssig brug af biblioteket, menogså til oplevelser iog på biblioteket øges stærkt.

Derfor skal de almene publikumsvendte funktioner ikke bare udbygges med en eller flere nye læesesale, en større informationssal, forsker-, møde- og undervisningsrum, menogsåmed tostoreudstillingssaletilhenholdsvisskiftendeudstillinger og Danmarks Bogmuseum, et Fotogalleri og en udstillingssal til Danmarks Fotomuseum, der tager udgangspunkti Kort-og Billedafdelingen, samt moderne faciliteter som foredrags/biografsal, restaurant/café og biblioteksshop.

\section{Specialcentre}

Gennem mange år har bibliotekets såkaldte særafdelinger, der i dag sammen med Danske Afdeling danner Nationalbiblioteksområdet, haft meget vanskelige 
betjenings- og formidlingsvilkår. Der har manglet publikumsvendte faciliteter tilpasset de særlige benyttelsesvilkår og sikringskrav, der må gælde for dette områdes materialer. Disse afdelinger, De boghistoriske Samlinger, Håndskriftafdelingen, Musikafdelingen, Kort-og Billedafdelingen, Judaistisk Afdeling og Orientalsk Afdeling, vil blive samlet i 4 specialcentre omkring hver sin læsesal med direkte tilgængelige referencesamlinger på åbne hylder, forskerrum, kontorer, betjenings- og nærmagasiner. Desuden vil de hver få en mindre udstillingssal i et særligt galleri for Nationalbiblioteksområdet.

\section{Kulturcentre}

Et afgørende spring frem imod kulturcenterideen bliver imidlertid dels inddragelsen af en række mindre selv̈stændige institutioner i bygningen, først og fremmest Det DanskeSprog-og Litteraturselskab, Dansk Folkemindesamling og Kvinfo (Center for Kvindestudier), dels integreringen af en mindrekoncertsal, der skal bygges med multifunktionelle formål for øje, en ide, der opstod i 1989/ 90 uafhængigt af bibliotekets oprindelige planer, men som i november 1992 blev integreret ud fra det hovedsynspunkt, at fællesfaciliteter udnyttes bedre, jo flere formål og aktiviteter de kan udnyttes til.

\section{Modernisering i historiske rammer}

Det kongelige Bibliotek gennemgik iårene 1986-1992en såkald tmodernisering, der indebar indførelsen af ny teknologi i alle funktionsled, omlægning af organisationen, sammensmeltning af to institutioner og nyvurdering af alle opgaver, funktioner, ressourceanvendelse og arbejdsmetoder. Udbygningen på Amager og i havnefronten fortsætter denne linie og bevarer frem for alt de mest værdifulde dele af Hans J. Holms bygning for dens oprindelige formål samtidig med, at en nutidig arkitekt får en enestående mulighed for at forny bygningskomplekset og hele Slotsholmen i et nyt århundredes perspektiv.

Processen blev gennemført under devisen Modernisering i historiskerammer for at understrege, at alle ændringer skulle ske i frugtbar vekselvirkning imellem fortid og nutid. Kronen på værket må i dette perspektiv siges at være en ny bygning i Havnefronten i både funktionel og arkitektonisk sammenhæng med de historiske bygninger, der på godt og ondt præger billedet af Det kongelige Bibliotek i offentligheden. 


\section{Litteratur og kilder}

Kell ElGSTRøM: Det kongelige Bibliotek - en bygning og dens arkitekt. København:

Det kongelige Bibliotek 1993.

HAKON LUND: Slotsholmen. København før og nu - og aldrig. Red. af Bo Bramsen. Bd. 1. København 1987.

Det kongelige Biblioteks gamle og ny Hjem. København 1906 - særudgave af artikler i Bogvennen 1904-1906.

Afhandlinger og artikler om Frederik III's biblioteksbygning:

KNUD BøGH i: Fund \& Forskning XII, XX og XXVI (1965-1983)

JАКOB H. GRøNB EK i: Magasin, årg. 2, 3 og 4 (1987-1989)

Artikler om Det kongelige Biblioteks byggesager og pladsproblemer:

IVAR HOEL [1867-1975] i: Meddelelser fra Rigsbibliotekaren, årg. 27 (1976),

MARTON DE HARTYANI [1860-1924] i:Magasin, årg. 3 (1928)

ERIK NøRR [1895-1901] i: Magasin årg. 4 (1989).

Nyere journalsager i Det kongelige Biblioteks arkiv. Interne Meddelelser, 28. årg. nr.

18, særnummer december 1992. 